\title{
LYST wt Allele
}

National Cancer Institute

\section{Source}

National Cancer Institute. LYST wt Allele. NCI Thesaurus. Code C52500.

Human LYST wild-type allele is located within 1q42.1-q42.2 and is approximately $223 \mathrm{~kb}$ in length. This allele, which encodes lysosomal-trafficking regulator protein, plays a role in the modulation of intracellular protein sorting. Mutations in the gene are associated with Chediak-Higashi syndrome. 